\title{
Книжная полка
}

ПЕВАР Стефен. Права индейцев и их племен. Руководство ассощиачии "Союз американских гражданских свобод" по правам индейцев и их племен/2-е изд.-Иллинойс, 1992. - 338 стр. PEVAR Stephen L. The Rights of Indians and Tribes: The Basic ACLU Guid to Indian and Tribal Rights/Second ed., Completely Revised and Up-to-Date. Southern Illinois University Press, 1992. - 338 p.

Эту книгу я выбрал среди тех, которые предложила мне профессор Университета Нью-Мексико Глория Валенсия-Вебэр, родом из горного индейского племени таос этого же штата. На юридическом факультете университета она читает курс "Индейское право". Выступая с лекциями в других учебных заведениях Калифорнии и НьюМексико, я удостоверился, что этот курс читается и там.

Индейцев иногда, в том числе в правовой литературе CIIA, называют "исконными американцами". Мне удалось посетить столицу штата Нью-Мексико - Санта-Фе, один из старейших по американским стандартам городов, основанный в 1606 году. Это по-прежнему в основном индейский город, и не только по составу населения. Среди многих городов мира такой я увидел впервые: вот уже несколько десятилетий решением Совета города в нем запрещено строить здания, будь то жилые или административные, которые по архитектурному виду не соответствовали бы старинному индейскому стилю. Эти красные одноэтажные и двухэтажные мазанки с современным интерьером удивительно красиво вписываются в ландшафт поросших кустарником каменистых предгорий. Эго город-музей, в нем более 300 обычных музеев индейской культуры. В этом регионе CIIA около трех десятков племен индейцев, живущих в поселениях (пуэбло) или резервациях (племена апачей, навахо и других, с детства известные нам по произведениям Ф. Купера). В современном благоустроенном и активно работающем Культурном центре индейских пуэбло в г. Альбукерке я беседовал с его директором Рафаэлем Гутьересом - доктором истории из племени апачей. Слушая его сетования на проблемы индейцев, живо вспоминал 
собственный опыт знакомства с плачевной жизнью коренных народов в северных районах Якутии и Камчатки...

В ноябре 1992 года Верховный Совет Российской Федерации принял в первом чтении проект Закона о статусе малочисленных народов* - "коренных народов" по международным стандартам. Он касается более 60 таких народов, населяющих север России, Сибирь, Дальний Восток, Приморье. Интересно сопоставить их положение и правовой статус с положением индейцев в CLIA.

Упомянутая выше книга - семнадцатая из серии - выпущена Союзом американских гражданских свобод. Ее автор - индеец из племени певар (Коннектикут), выпускник знаменитого Принстона и профессор Денверского университета. Обращение к индейцам Ст. Певар начинает словами: "Данное руководство излагает ваши права по действующему закону и говорит о том, как они могут быть зашищены" (с. VII). Вряд ли кто-либо из наших читателей знает из лекционных курсов и книг о таком средстве защиты прав коренного народа, как индейская судебная система. Такая система автономно существует в "индейских" штатах наряду с федеральными судами и судами штата. В восьми штатах сила постановлений индейских судов признана законом. Нижняя ступень судебной системы - племенные суды, верхняя - межплеменные апелляционные суды. Параллельно существуют и обычно-правовые суды - так называемые суды примирения, или суды старейшин. Эта система действует в большинстве из 27 штатов, где живут индейцы, охватывая практически почти все 300 резерваций. Но не во всех этих штатах она признана законом.

Путь к возникновению этой национальной системы судов был, как известно, кровавым и жестоким. Из более чем 400 племен с миллионным населением к 1900 году, как пишет автор, осталось несколько десятков численностью 300 тыс. человек. Сегодня индейцев - около 1,5 млн., указывается в книге, и жизнь их на треть короче среднеамериканской; среди индейцев наиболее высока безработица, самые низкие доходы, худшие жилищные условия, половина взрослых не имеет высшего образования (с. 1).

* По нашему мнению, В названии проекта закона и формулировках положений статей допущена подмена понятия "коренной народ" на "малочисленшый". Юридическим следствием этого является то, что на малочисленжые народы в нашей стране не будут распространяться международно-признанные права и привилегии. 
Федеральная политика в отношении индейцев неоднократно совершала крутые зигзаги - "от признания племен суверенно равными $\kappa$ переселению племен, к попыткам ликвидировать или ассимилировать их и, наконец, ныне к поощрению племенного самоопределения" (с. 2). Хронологически это выглядит следующим образом: 1492-1787 годы - племенная независимость; 1787-1828 годы соглашения равных; 1828-1887 годы - переселение индейцев; 1887-1934 годы - политика ассимиляции; 1934-1953 годы - период восстановления, начатый Д. Рузвельтом; 1953-1968 годы - прекращение поддержки индейцев. С 1968 года была провозглашена политика "племенного самоопределения". Каждый из этих периодов был отмечен введением соответствующего законодательства.

Начиная с 60-x годов нашего века Конгресс принял ряд законодательных актов, "которые ускорили самоопределение и развитие индейцев" (с. 8). Среди основных, упоминаемых Ст. Певаром: Акт о самоопределении индейцев и содействии их образованию (1975 г.) и законодательный запрет штатам приобретать какие бы то ни было права над резервациями без согласия на то данного племени (1968 г.). Упомянуты также акты о создании Фонда развития индейского бизнеса, о финансировании индейцев, о программах исконных американцев. В числе принятых в последние годы: Акт о развитии минеральных ресурсов индейцев, Акт о статусе индейских племен в отношении правительственных налогов и, наконец, Акт о регулировании игрового бизнеса среди индейцев (1988 г.). Система этих актов доказывает, по мнению Верховного суда CIIA, что "как племена, так и федеральное правительство твердо привержены цели развития племенного самоопределения - цели, воплощенной в ряде федеральных законоположений" (с. 9).

Специальная глава рецензируемой работы посвящена анализу утвердившейся в судебной практике и доктрине СІІА концепции "ответственности доверия". Речь идет о том, что в течение 1787-1871 годов индейские племена заключили сотни договоров с федеральными властями относительно своих территорий в обмен, по существу, на обещания. "Эти обещания создали "обязательство защищать" индейцев, - пишет автор, - ... основа этих уникальных отношений доверие: индейцы верят Соединенным Штатам в том, что те выполнят обещания, которые дали в обмен за их земли" (с. 26). Анализируя судебную практику, автор приходит к выводу, что такая ответственность не только возникает из явного закрепления ее в соглашении или законе, но может и подразумеваться. Кроме того, она выте- 
кает из общей "обязанности федерального правительства быть лояльным В отношении индейцев и содействовать их интересам, включая стремление к самоуправлению" (с. 27).

Анализируя вопрос о самоуправлении индейцев, Ст. Певар пишет: "Индейские племена имеют неотемлемое право самоуправления. Они обладали этим правом веками до того, как впервые вошли в контакт с внешним миром. И они должны иметь его сегодня" (c. 79). Однако власть племени имеет, по мнению автора, два ограничения: явное и подразумеваемое. Пример первого - запрет продавать племенную землю без разрешения федерального правительства. Второе ограничение - недопустимость заключения племенем соглашений с иностранными правительствами. Верховный суд США охарактеризовал такое положение правительств племен как "квазисуверенное" и "полунезависимое": формально они обладают властью над своими членами и своей территорией, но за 200 лет существования США они так ослабли, что "лишь немногие племена в состоянии осуществлять все свои права" (с. 81). К правам, которые имеют племена, относятся: право создавать свое правительство; определение вопросов членства в племени; регулирование вопросов племенной, а также частной собственности; сбор налогов; контроль за соблюдением закона и порядка; право юрисдикции (гражданской) в отношении неиндейцев на подведомственной территории; право регулировать свои дела, отношения между членами племени; право регулировать вопросы коммерции и торговли племени и его членов; другие права. В соответствии с договорами прошлого и судебной практикой подтверждается право индейцев на охоту, рыболовство и сбор ягод, трав и корнеплодов, причем не только в пределах своей резервации, но в ряде случаев и за ее пределами (c. 179-208).

Интересно, что некоторые племена индейцев имеют особый статус. Так, пуэбло в Нью-Мексико наиболее свободны от федерального вмешательства. 80 тыс. коренных жителей Аляски по Аляскинскому акту (1971 г.) об урегулировании требований коренного населения о порядке компенсации за изъятие в прошлом их земель получили около 1 млрд. долл. СІІА и 40 млн. акров земли в собственность (с.254). Особым положением пользуются и индейцы Оклахомы, поскольку в прошлом их практически лишили земель. Статус ирокезских племен в Нью-Йорке определяется тем, что штату передано пргизводство по всем уголовным делам, стороной в которых является индеец или группа индейцев. 
К категории индейцев, находяшихся на особом положении, автор относит и так называемые "непризнанные племена" - те, которые не признаны федеральным правительством официально. Сейчас более 400 групп индейцев претендуют на то, чтобы иметь статус племени (с. 261). Это связано с тем, что все специальные программы правительства СІІА, а также законодательство рассчитаны на "признанчые" племена. Это обстоятельство свидетельствует о том, что борьба индейцев за свои права еще не закончена.

Не только анализом прав индейцев и их племен, но и указанием на новые возможности расширения таких прав интересно рассмотренное "Руководство для индейцев". Поднятые в этой книге вопросы весьма актуальны также с той точки зрения, что в Российской Федерации начат процесс законодательного закрепления статуса так называемых малочисленных народов, а в немалой степени еще и потому, что ООН объявила 1993 год Годом коренных народов.

P.A. ТУЗМУХАМЕДОВ, доктор юридических наук, nрoфeccop 